DOI https://doi.org/10.18551/rjoas.2021-01.12

\title{
PREDATOR DIVERSITY AS NATURAL ENEMIES OF INSECT PESTS ON PADDY FIELD ECOSYSTEM IN PIDIE AND PIDIE JAYA REGENCIES, ACEH PROVINCE, INDONESIA
}

\author{
Munawar \\ Master's Program of Agroecotechnology, Faculty of Agriculture, Syiah Kuala University, \\ Banda Aceh, Indonesia \\ Husni, Jauharlina* \\ Department of Plant Protection, Faculty of Agriculture, Syiah Kuala University, \\ Banda Aceh, Indonesia \\ *E-mail: ljauharlina@unsyiah.ac.id
}

\begin{abstract}
This study aims to determine the diversity of natural enemies, especially predatory arthropod found in farmers' paddy fields in Pidie and Pidie Jaya Regencies, Aceh Province, Indonesia. The research samples were taken 3 times at the age of 30,45 , and 60 days after transplanting (DAT). Parameters observed included identification of predator morphospecies, the abundance of predator individuals, also diversity, evenness, dominance, and similarity indices of predators. The results showed that the number of predator morphospecies and the abundance of individual predators in paddy rice in Pidie Jaya Regencies tended to be higher than those of paddy field in Pidie Regencies. The index value of predatory diversity in paddy fields in the two regencies was in a good category where the community ecosystem conditions were more stable. The evenness index of predatory evenness in the observation 30 and 45 DAT in the two regencies was in a good category with more stable community ecosystem conditions, but at 60 DAT observations in the two regencies, the index value of the evenness was even in an excellent category with very stable community ecosystem conditions. The dominance index value of paddy fields in the two regencies was a low category $(<0.5)$, meaning predator morphospecies were very diverse. Observations on the similarity index of predator morphospecies showed that the level of community similarity between the two regencies was 0,76 based on the Kendeigh index value. This showed that there were about $76 \%$ of the same predatory morphospecies in Pidie and Pidie Jaya Regencies.
\end{abstract}

\section{KEY WORDS}

Arthropods, insect sampling, rice, biological control.

Rice (Oryza sativa L.) is the most essential food crop in Indonesia because more than half of Indonesia's population consumes rice produced from paddy plants. Rice is an annual crop making its ecological conditions keep changing and causing an unstable balance between pest populations and natural enemies (predators, parasitoids, and pathogens). A break in the planting period frequently happens in seasonal crops which will result in no development of natural enemies and pests to increase continuously without any limiting factors from nature (Azmi et al., 2014). Cultivation of rice, which is often monoculture, can encourage paddy field ecosystems that are vulnerable to plant pests (OPT). One of the drivers of the increase in plant pests is the continuous availability of food at all times and in every place (Altieri et al., 2004).

The problem faced by farmers nowadays is how to control the plant pests (OPT) properly and safely. The control by using synthetic pesticides can reduce yield losses due to pests, but also cause negative impacts on the environment such as killing natural enemies causing the pest population increases (Herianto et al., 2015). The utilization of natural enemies is one of the ways of controlling pests in a biological way that can minimize the pest population. Biological control means controlling by exploiting natural enemies such as 
predators, parasitoids, and pathogens. Pest control with predators is a very strategic alternative way of controlling pest attacks on paddy plants (Herianto et al., 2015).

The biggest problem in the field at this time is the lack of knowledge of farmers about the types of predators in the plantations because so far farmers do not recognise the difference between insect pests and predators, so all insects are considered pests. Predators are animals or insects that can prey on other insects living freely in nature to make ends meet. Predators need some prey during their lives so that they can be used in reducing the number of pest populations in the field. Most predators are polyphagous meaning they prey on a wide variety of different insects. In addition, some predators are cannibals, meaning they prey on each other. In lowland paddy plants, the most common predators are from the Carabidae, Formicidae and Lycosidae families (Herlinda et al., 2008), and the results of research in Aceh Besar District also indicated that the predominant species of predators are the most dominant and have a high number of individuals from the insect species such as Agriocnemis Femina (Odonata: Coenagrionidae), Tetragnatha Maxillosa spiders (Araneae: Tetragnathidae) and Verania Lineata insects (Coleoptera: Coccinellidae) (Jauharlina et al., 2019).

One of the limitations of farmers in conducting biological control as part of an integrated pest control strategy is the limited knowledge of the role of the arthropod groups found in their fields, so they often spray synthetic pesticides when looking at arthropod species in paddy fields, especially insects. This research was conducted to identify predator species and to determine the diversity and structure of the predator community in paddy ecosystems planted by local farmers.

\section{MATERIALS AND METHODS OF RESEARCH}

Artropod Sampling. This research was conducted in Pidie and Pidie Jaya Regencies from September 2018 to June 2020. These two regencies are rice-producing areas in Aceh Province. Arthropod sampling was carried out using sweeping nets and pitfall traps from 16 paddy farmers' fields in the two regencies. The land size ranged from $1.100 \mathrm{~m} 2$ to $3.400 \mathrm{~m} 2$ with different varieties of rice planted for each land. The use of synthetic pesticides in these two regencies was still the mainstay of farmers in controlling pest attacks, which ranged from two to five times per rice planting season.

Samplings using sweeping nets and pitfall traps in Pidie and Pidie Jaya Regencies were conducted between 4 p.m - 6 p.m of Western Indonesian Time, the sub-sample area was at least $10 \%$ of the whole land area consisting of five sub-samples in each land. The determination of the sub-samples was done by using the diagonal slice method, which was four on the outer side and one in the middle of each plot (Figure 1). Arthropod sampling was carried out 3 times, which was at the age of 35, 45 and, 60 days after transplanting (DAT). Arthropod samples taken were especially aimed at those flying above the rice surface and those near paddy plants. The arthropod samples obtained in the sub-sample fields were stored in plastic bottles containing $70 \%$ alcohol and labeled based on the sampling location, and then taken to the Biological Control Laboratory of the Agriculture Faculty, Universitas Syiah Kuala for further identification. The number of individuals from each category of arthropods was counted to determine the population size.

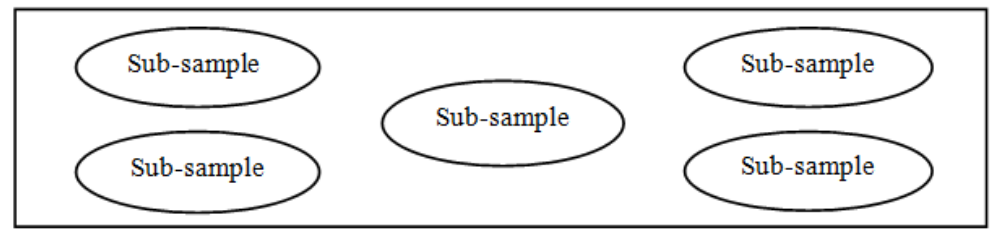

Information:

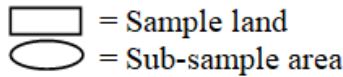

Figure 1 - Location for taking sub-samples from each sample plot 
The sweeping net used was in the form of a cone, the net mouth was made of circular wire with a diameter of $30 \mathrm{~cm}$, the net was made of gauze and $60 \mathrm{~cm}$ long wooden nets. Sampling of pest insect predators was conducted in each sub-sample area by swinging the net left and right back and forth 10 times while walking. The Pitfall trap method used plastic cups which were commonly utilised as containers for mineral drinking water with a volume of $\pm 240 \mathrm{ml}$, a diameter of $6 \mathrm{~cm}$ and a height of $10 \mathrm{~cm}$. Pitfall traps were installed in the paddy fields' embankment by implanting the cups into the soil at each sub-sample array observed where the surface was flat with the soil surface. The top of the container was covered with iron sheeting as a roof to prevent water from entering when raining and a wooden pole was also installed $5 \mathrm{~cm}$ high from the ground. In total, there were eight traps were installed in each sub-sample of the observed areas. The installation of Pitfall traps was carried out for 24 hours before sampling started from 4 p.m -6 pm of Western Indonesian Time.

Data Analysis. Diversity and abundance data of insect pest predators were analyzed by determining the abundance of individual predators, the Shannon-Wienner diversity index $\left(\mathrm{H}^{\prime}\right)$, the predator evenness index (E), the predominance index (D), and the similarity index (IS). The data obtained were tabulated in tables and diagrams by comparing the percentage of the number of predatory morphospecies between Pidie and Pidie Jaya Regencies. Comparison of data between the two regencies was analyzed with the $T$ test. The significant difference between the two regencies was set at $P<0.05$.

\section{RESULTS AND DISCUSSION}

Predator Identification. The samples collected on rice plants for three times of observations at 30, 45, and 60 DAT in Pidie Regencies were 1.923 predatory individuals belonging to 5 orders, 15 families, and 19 morphospecies. While in Pidie Jaya Regencies with the same observation time we found 6 orders, 16 families, and 20 predatory morphospecies with a total of 2.083 predatory individuals. The identification of predators was done based on their morphology which was referred to previous study in a different area (Jauharlina et al., 2019). The number of predatory morphospecies in lowland rice in Pidie Jaya Regencies was generally higher than that of predatory morphospecies in rice in Pidie Regencies, although there was no significant difference between them ( $t$-Test $P=0,06$, $t=-1,98$, df $=14$ ). The average number of predatory morphospecies per land in paddy plants in Pidie Regencies ranged from 1,38-2,38, while in Pidie Jaya Regencies the number of predator morphospecies per land was 2,13-2,50 (Figure 2).

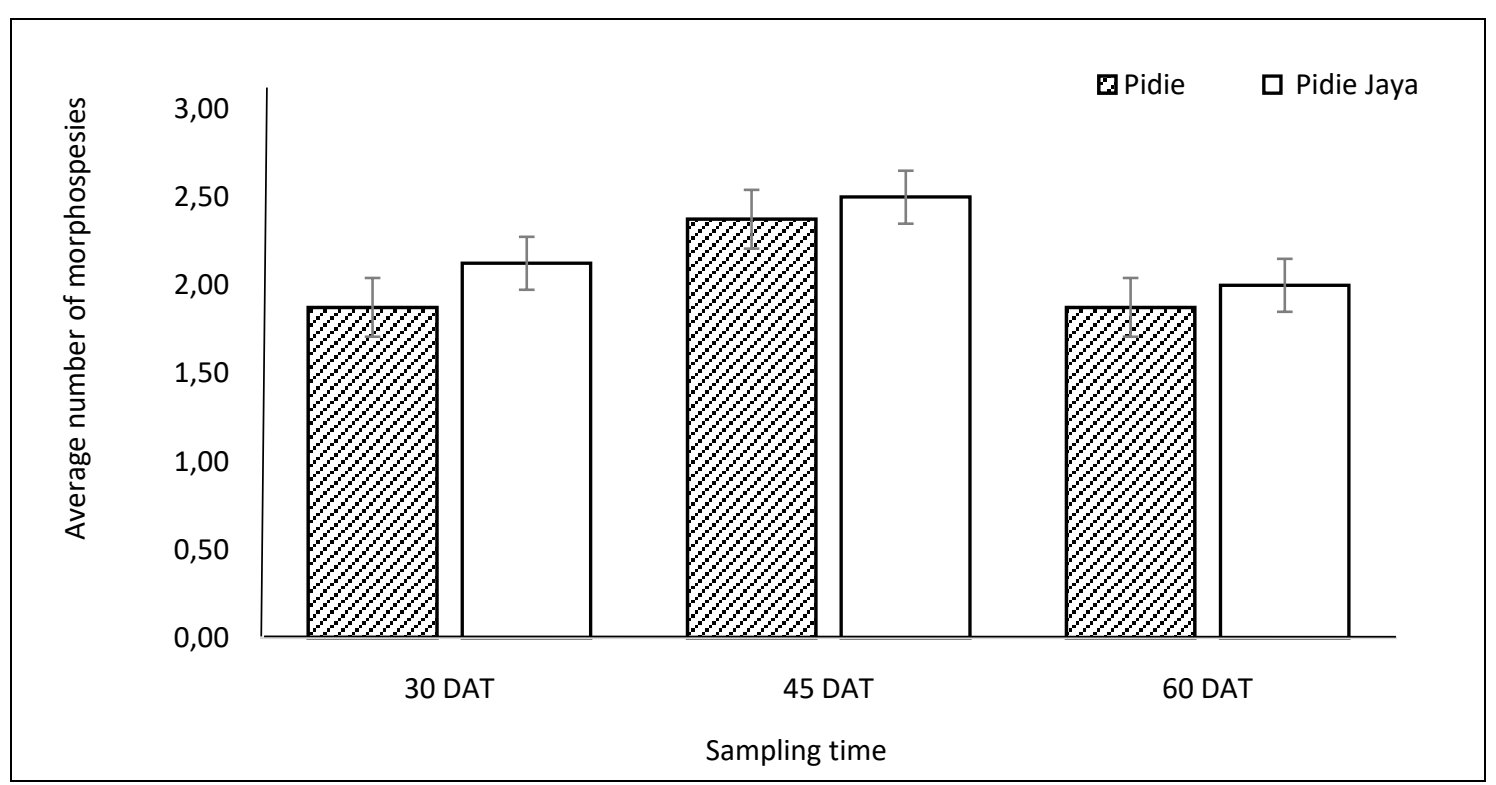

Figure 2 - Average number of predator morphospecies per land in paddy fields in Pidie and Pidie Jaya Regencies at 30, 45 and 60 days after transplanting (DAT) 
The results showed that the predatory morphospecies that were always found in each sampling area in the two regencies belonged to the Araneidae, Tetragnathidae, Ephydridae and Coenagrionidae families. This was presumably because there was a lot of prey from each of this predatory morphospecies on each rice plant sampling area. The Araneidae family of the Araneae order is a predator possessing a wide distribution area and likes to be on the stalks of paddy plants. This is because the spiders of this family are nocturnal predators that are more active at night and will choose to rest in the nest during the day, so they choose a place with low light for nesting. The spiders of the Araneidae family are known as spinning spiders making circular nests and wait for their prey in the middle of their strong webs, so they can last up to several days. The main prey of the Araneidae family are flies, leafhoppers and rice stem planthoppers (Diniyati et al., 2018).

Tetragnathidae is a family of predators also classified into the spider group. The Tetragnathidae family of the Araneae order is very active in attacking prey at night, while during the day this family is mostly standing alone. The primary prey of the Tetragnathidae family are brown leafhoppers, green leafhoppers and back leafhoppers and are able to prey on 2-3 leafhoppers/day (Asikin, 2014).

The high number of morphospecies from the Diptera order of the Ephydridae family is because the research location is in the lowland rice ecosystem which is watery soil. Ephydridae larvae live in water, and when they mature, they are in rice plantations in search of prey and shelter, so the Ephydridae insects are abundant (Masfiyah et al., 2014). Daly et al. (1978) also stated that the ones that dominate aquatic insects are the larvae of the order Diptera, including the Ephydridae family.

The Coenagrionidae family of the Odonata order known as dragonflies is also the dominant insect in lowland paddy plants in the vegetative phase, the Coenagrionidae life cycle ranges from 10-30 days with the number of eggs produced by a female for the amount of 30 eggs. Premature insects live in aquatic habitats and act as predators of mosquito larvae, while adult insects prey on small flies and bugs (Herianto et al., 2015).

The Abundance of Individual Predators. The observation results on the abundance of individual predators of the whole morphospecies in paddy plants in Pidie and Pidie Jaya Regencies with sampling time at the age of 30,45 and, 60 days after transplanting (DAT) can be seen in Figure 2 and Figure 3.

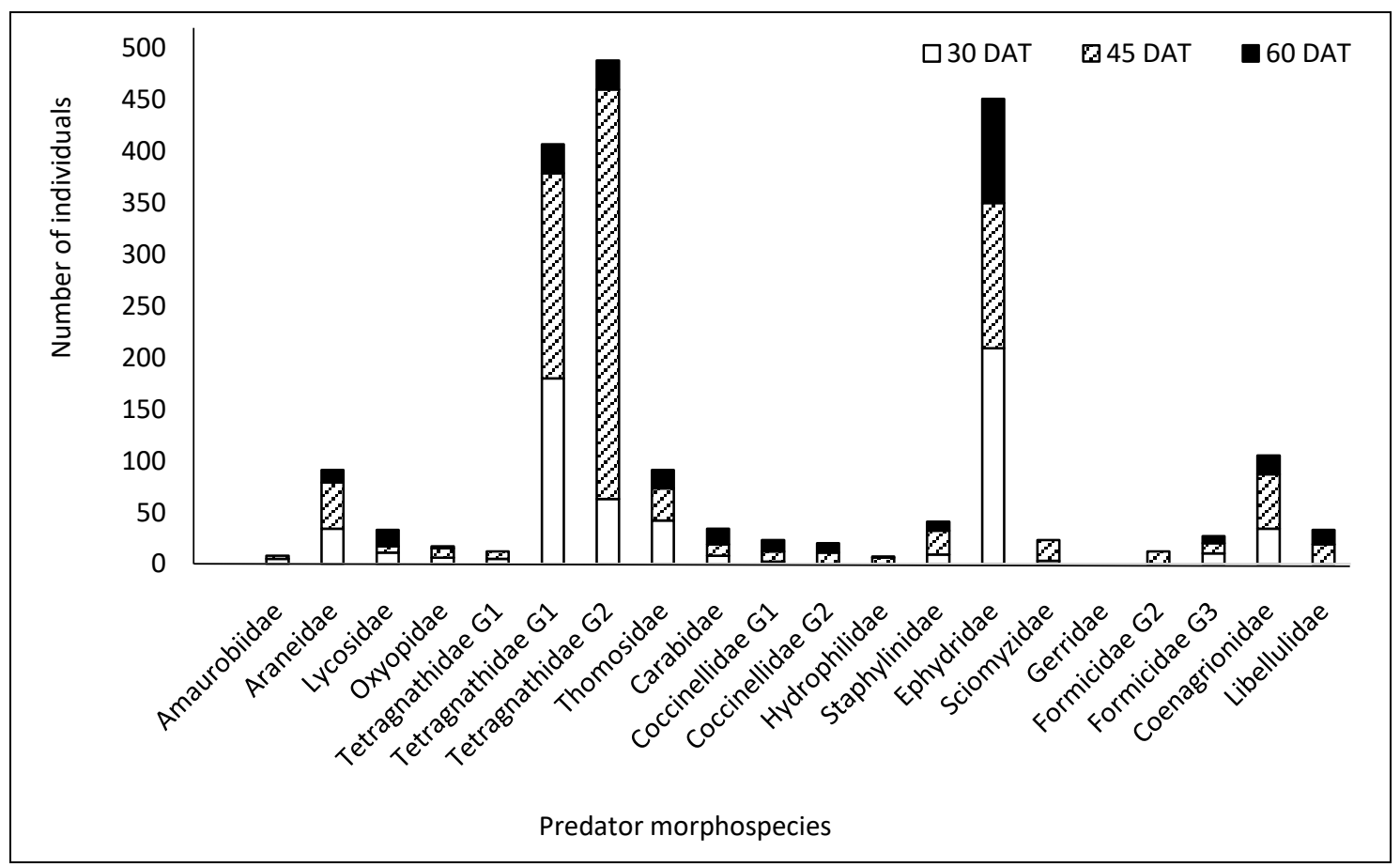

Figure 3 - Abundance of individual predators at 30,45 and 60 days after transplanting (DAT) on paddy plants in Pidie Regency 


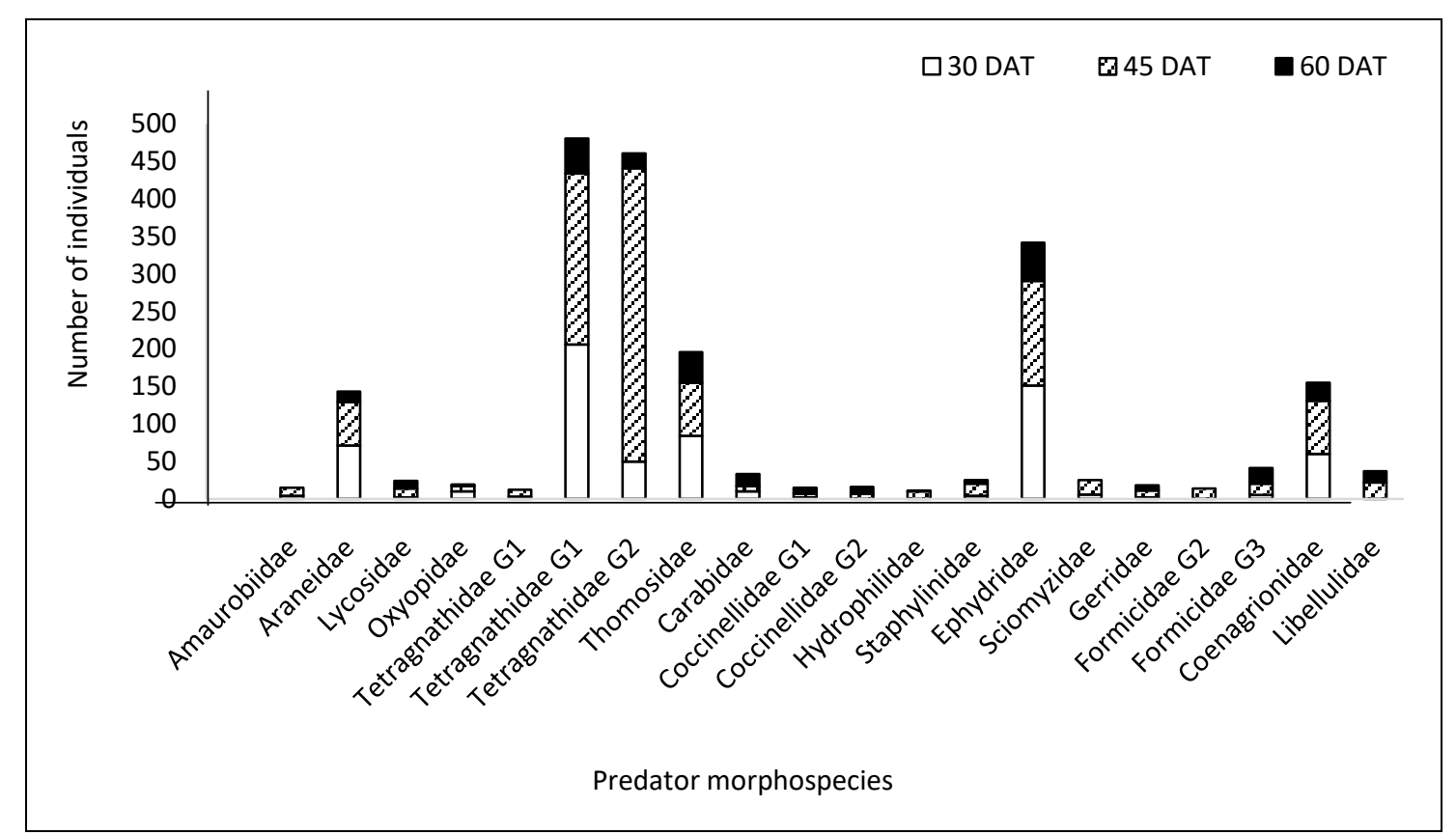

Figure 4 - The abundance of individual predators at 30,45 and 60 days after transplanting (DAT) on paddy plants in Pidie Jaya Regency

Based on the sampling results in Pidie and Pidie Jaya Regencies, the abundance of individual predators has increased from the age of paddy plants 30 DAT to 45 DAT. The increasing abundance of individual predators in Pidie Jaya and Pidie Regencies on paddy plants aged 45 DAT was due to the higher availability of prey and hosts for these predators. Paddy plants have entered a generative phase where insect pests have begun to develop and are found around paddy fields. However, on observations at 60 DAT, there was a decrease in the abundance of individual predators in Pidie and Pidie Jaya Regencies. This is because farmers spray pesticides at the age of 50 DAT in both regencies even though the paddy plants have entered the generative phase. The higher the application of synthetic pesticides, the higher chance of the pest population will decrease. This also causes a decrease in natural enemies especially predators, both due to the impact of synthetic pesticides and the reduction of prey from these natural enemies. Herianto et al. (2015) also stated that the ability and behavior of a natural enemy, especially a predator, greatly affects the density and type of prey, the higher the density of a prey population, the higher the predatory ability of these predators will increase.

The low number of predatory morphospecies individuals found in Pidie Regency compared to Pidie Jaya Regency at each sampling of plant age is thought to be due to the high application of synthetic pesticides in Pidie Regency as many as 5 applications/planting season depending on pest attack so that the reduction of natural predatory enemies while in Pidie Jaya Regency it was only done 2 times. This research is in line with the opinion of Kartohardjono (2011) stated that the use of synthetic pesticides in lowland rice is very effective in controlling pest attacks, but at the same time, it can also reduce the population of natural enemies significantly, which have the ability to control pests. In addition, the inadvisable use of synthetic pesticides can also cause pollution to the environment which has adverse effects on human health.

Diversity Index ( $\left.H^{\prime}\right)$, Evenness Index $(E)$, and Dominance Index $(D)$. The observation results on the average diversity index, closeness index, and predominance index at the age of 30,45 , and 60 days after transplanting (DAT) in Pidie and Pidie Jaya Regencies are presented in Table 1.

The analysis results of predatory morphospecies diversity in Pidie and Pidie Jaya Regencies at the age of 30,45, and 60 days after transplanting (DAT) showed that the level of predatory morphospecies diversity was more stable, meaning that the diversity of 
predatory morphospecies was considered good based on the weighted assessment criteria of Krebs environmental quality (1989). Haneda et al. (2013) said that the diversity index value in an ecosystem is strongly influenced by the environmental conditions of the community and depends on the variation in the number of individual predators obtained. In addition, the diversity index value is also strongly influenced by factors of quality and quantity of food, including the number of suitable host plants, the density of the host plant and the age of the host plant. Furthermore, Widiarta et al. (2006) added that the diversity index value of a paddy field ecosystem would be high if synthetic pesticides were not applied to the fields.

Table 1 - Average index values of diversity, evenness and dominance in paddy plants in Pidie and Pidie Jaya Regencies at 30, 45, and 60 days after transplanting (DAT)

\begin{tabular}{|c|c|c|c|}
\hline \multirow[t]{2}{*}{ Sampling Location } & $\begin{array}{l}\mathrm{H}^{\prime} \text { Index } \\
\text { (Average } \pm \text { SE) }\end{array}$ & $\begin{array}{l}\text { E Index } \\
\text { (Average } \pm \text { SE) }\end{array}$ & $\begin{array}{l}\text { D Index } \\
\text { (Average } \pm \text { SE) }\end{array}$ \\
\hline & $30 \mathrm{DAT}$ & & \\
\hline Pidie District & $1,81 \pm 0,03$ & $0,75 \pm 0,01$ & $0,24 \pm 0,01$ \\
\hline \multirow[t]{2}{*}{ Pidie Jaya District } & $1,86 \pm 0,03$ & $0,79 \pm 0,01$ & $0,20 \pm 0,01$ \\
\hline & 45 DAT & & \\
\hline Pidie District & $1,93 \pm 0,03$ & $0,72 \pm 0,01$ & $0,23 \pm 0,01$ \\
\hline \multirow[t]{2}{*}{ Pidie Jaya District } & $2,03 \pm 0,03$ & $0,75 \pm 0,01$ & $0,20 \pm 0,01$ \\
\hline & 60 DAT & & \\
\hline Pidie District & $2,02 \pm 0,03$ & $0,84 \pm 0,02$ & $0,18 \pm 0,01$ \\
\hline Pidie Jaya District & $2,21 \pm 0,04$ & $0,92 \pm 0,02$ & $0,13 \pm 0,01$ \\
\hline
\end{tabular}

Information: $H^{\prime}$ - Diversity Index; $E$ - Evenness Index; $D$ - Dominance Index.

The results of observing the evenness index value of lowland paddy plants in Pidie and Pidie Jaya Regencies at 30 and 45 days after transplanting showed that the evenness level of predatory morphospecies was in a good category with a more stable community ecosystem structure, while the evenness index value was in the two regencies at the age of 60 days after transplanting, indicated that the evenness level of predatory morphospecies was in the excellent category with a very stable community ecosystem structure based on the weighted assessment criteria for environmental quality Krebs (1989). Arifin et al. (2016) reported that the evenness index of an insect habitat is influenced by environmental factors including the ability of these insects to spread, habitat selection, air temperature conditions, light, rainfall and vegetation and food availability.

The observation results of the dominance index value in lowland paddy plants in Pidie and Pidie Jaya Regencies showed that the dominance level of predatory morphospecies was in a low category, which was $<0.5$ based on the Margelaf dominance assessment criteria (1958), meaning the dominance/wealth of predatory morphospecies in Pidie and Pidie Jaya is very diverse.

Subiyakto (2011) also stated that if the dominance index value is $<1$, the number of predator morphospecies is diverse, on the contrary, if the dominance index value $=1$, there is no diversity and evenness of predator morphospecies in an ecosystem. The high dominance of predatory morphospecies is influenced by biotic and abiotic factors as well as changes in the chemical environment due to metabolic secretions, lack of food, predator/parasite/disease attacks, the emigration of climatic factors such as weather, temperature and humidity can affect the density of a population.

The diversity, evenness and dominance index of predatory species is a depiction to show the diversity and distribution of an organism species. In addition, it can also describe the pressure on ecosystems and ecosystem productivity to the stability of an ecosystem (Magurran, 1996).

Table 2 - The value of the similarity index (IS) in lowland rice between Pidie and Pidie Jaya Regencies calculated based on three observations at 30,45 , and 60 days after transplanting

\begin{tabular}{ll}
\hline Sampling Location & Similarity Index (IS) \\
\hline Pidie District & $76,92 \%$ \\
Pidie Jaya District & \\
\hline
\end{tabular}


Predator Similarity Index (IS). The calculation results of the similarity index value in lowland rice between Pidie and Pidie Jaya Regencies show that the similarity index value (IS) of predatory morphospecies is (IS = 76.92\%) (Table 2) which is in a similar category to the predatory morphospecies community composition in the two lowland rice cultivation is based on the criteria for the similarity index assessment criteria according to Kendeigh (1980). This is in line with the opinion of Mawazin and Subiakto (2013) stated that the lower the composition of different predatory morphospecies species, the higher the similarity index value, and vice versa, if the more types of predator morphospecies composition are different, the lower the predatory morphospecies similarity index.

\section{CONCLUSION}

The results showed that the whole arthropods were taken as samples categorized as phytophages, spiders and predatory insects. The total number of arthropod morphospecies found in Pidie Regencies was 19 arthropods, while in Pidie Jaya Regencies was 20 arthropod morphospecies discovered. Compared to other predatory morphospecies, the predatory morphospecies is most commonly found and have a high number of individuals in each sampling area of lowland paddy plants in Pidie and Pidie Jaya Regencies are species from the family (Araneae: Araneidae), (Araneae: Tetragnathidae), (Diptera: Ephydridae), and (Odonata: Coenagrionidae). The diversity index value $\left(\mathrm{H}^{\prime}\right)$ of predatory morphospecies in lowland rice fields in the two regencies was in the good category with more stable community structure conditions. The evenness index value (E) of predatory morphospecies at paddy plants' age in 30 and 45 days after transplanting in the two regencies was in the good category with the condition of the community structure more stable, while the observation 60 days after transplanting the evenness index value in the two regencies was excellent with very stable community structure conditions. The dominance index value (D) of predatory morphospecies in lowland paddy plants in the two regencies was in a low category, meaning the predator morphospecies is very diverse, and the similarity index (IS) value of predatory morphospecies in lowland rice is in the same community category. The presence of this predator may play an important role in controlling the pest population in the observed paddy fields.

\section{REFERENCES}

1. Altieri MA, Gurr GM, Wratten SD. 2004. Ecological Engineering for Pest Management: Advances in Habitat Manipulation for Arthropods.Ithaca, New York (NY). Stock Publishing Associates. $238 \mathrm{p}$.

2. Arifin L, Irfan M, Permanasari I, Annisava AR, Arminudin AT. 2016. Keanekaragaman serangga pada tumpang sari tanaman pangan sebagai tanaman sela di pertanaman kelapa sawit belum menghasilkan (The diversity of insects in intercropping food plants as intercrops in immature oil palm plantations). Jurnal Agroteknologi. Vol. 7(1): 33-40.

3. Asikin S. 2014. Serangga hama and serangga musuh alami yang berasosiasi pada tumbuhan air dominan di lahan rawa pasang surut (Natural pests and insect enemies associated with dominant aquatic plants in tidal marshlands). Prosiding Seminar Nasional "Inovasi Teknologi Pertanian Spesifikasi Lokasi" (Proceedings of the National Seminar "Agricultural Technology Innovation with Location Specifications".). Hal. 385-394. 6-7 Agustus 2014. Banjarbaru.

4. Azmi SL, Leksono AS, Yanuwiadi B, Arisoesilaningsih E. 2014. Diversity of Herbivore Arthropods Visitor on Red Paddy Variant in Organic. Journal of Sustainable Development. Vol. 5 (1): 57-63.

5. Daly HV, Doyen JT, Ehrlich PR. 1978. Introduction to Insect Biology and Diversity. International Student Edition. Tokyo: Mc. Graw-Hill, Kogakusha.

6. Diniyati F, Dahelmi, Herwina H. 2018. Laba-Laba Famili Araneidae pada Kawasan Cagar Alam Lembah Anai Kabupaten Tanah Datar, Sumatera Barat (Araneidae family spiders in 
the Anai Valley Nature Reserve, Tanah Datar District, West Sumatra). Jurnal Biologi Universitas Andalas. Vol 6 (2): 15-22.

7. Haneda NF, Kusuma C, Kusuma FD. 2013. Keanekaragaman Serangga di Ekosistem Mangrove (Insect Diversity in the Mangrove Ecosystem). Jurnal Silvikultur Tropika (Journal of Silvikultur Tropika). Vol. 4 (2): 42-46.

8. Herianto IK,Moulwy F, Wanta NN. 2015. Serangga predator pada ekosistem padi sawah di Kecamatan Tombatu, Kabupaten Minahasa Tenggara (Predatory insects in the lowland rice ecosystem in Tombatu District, Southeast Minahasa District). Penelitian Pertanian (Agricultural Research). Vol. 6 (6):1-20.

9. Herlinda S, Waluyo, Estuningsih P, Irsan C. 2008. Perbandingan keanekaragaman spesies and kelimpahan Arthropoda predator penghuni tanah di sawah lebak yang diaplikasi Insektisida and tanpa aplikasi Insektisida (Comparison of species diversity and abundance of soil-dwelling predatory arthropods in wet rice fields with insecticides and no insecticides). Jurnal Entomologi Indonesia (Journal of Entomology Indonesia). Vol. 5(2):96-107.

10. Jauharlina, Hasnah, Taufik IM. 2019. Diversity and Community Structure of Arthropods on Rice Ecosystem in Aceh. AGRIVITA. Journal of Agricultural Science. Vol. 41 (2): 316 324.

11. Kartohardjono A. 2011. Penggunaan musuh alami sebagai komponen pengendalian hama padi berbasis ekologi (The use of natural enemies as a component of ecologybased rice pest control). Jurnal Pengembangan Inovasi Pertanian (Journal of Agricultural Innovation Development). Vol. 4 (1): 29-46.

12. Kendeigh SC. 1980. Ecology with Special Reference to Animals and Man. Prentice Hall of India. New Delhi.

13. Krebs CJ. 1989. Ecological methodology. New York, NY: Harper and Row Publishers Inc., $654 \mathrm{p}$.

14. Magurran AE. 1996. Ecological Diversity and Its Measurement. Chapman and Hall, London. $175 \mathrm{p}$.

15. Margelaf R. 1958. Information theory in ecology. General Systems. 3: 36-71.

16. Masfiyah E, Karindah S, Puspitarini DR. 2014. Asosiasi Serangga Predator and Parasitoid dengan Beberapa Jenis Tumbuhan Liar di Ekosistem Sawah (Association of Predator and Parasitoid Insects with Several Types of Wild Plants in Rice Field Ecosystems). Jurnal HPT. Vol. 2 (2): ISSN: 2338-4336.

17. Mawazin, Subiakto A. 2013. Keanekaragaman and komposisi jenis permudaan alam hutan rawa gambut bekas tebangan di Riau (Diversity and species composition of natural regeneration of logged-over peat swamp forests in Riau). Pusat Litbang Konservasi and Rehabilitasi (Conservation and Rehabilitation Research and Development Center). Bogor.

18. Subiyakto. 2011. Teknologi pengendalian hama berbasis ekologi dalam mendukung pengembangan kapas (Ecology-based pest control technology to support cotton development). Balai Penelitian Tanaman and Serat (Research Institute for Plants and Fiber). Malang.

19. Widiarta IN, Kusdiaman D, Suprihanto. 2006. Keragaman artropoda pada padi sawah dengan pengelolaan tanaman terpadu (Arthropod diversity in lowland rice with integrated crop management). Jurnal Hama Penyakit Tumbuhan Tropika (Journal of Tropical Plant Disease Pests). Vol. 6 (2): 61-69. 